\title{
UNDERSTANDING OF LATVIAN STUDYING YOUTH ABOUT MOBILITY AND MIGRATION IN MULTI-DIMENSIONAL SOCIETY NOWADAYS
}

\begin{abstract}
SUMMARY
Introduction. Rapid inhabitant mobility and migration to European and other countries in the world as well as in the territory of Latvia goes on since Latvia has become the member of the European Union. There are several possible reasons for that: economic crisis in the country, low salaries in the social state sector, individual strivings and aspirations of every person to achieve self-realization. Many children become parentless as parents go to different countries. A part of Latvia's inhabitants come back but a part of them continue to live abroad. This was the reason for choosing the topic to study.

The Aim of the Study. To investigate circumstances why inhabitants of Latvia leave their country and what the civic understanding of the Latvian young people, who study in tertiary institutions, is as regards the mobility and migration to a different society.

Materials and Methods. European project Multiple Choice Identity: Materials of Mobility and Migration. Statistical data and analysis and research about migration. Interviewing students in an empiric investigation; interviewing people who have emigrated to England.

Results. Mobility and migration have positive and negative economical and demographic consequences; it is important for every nation to preserve its cultural identity. Particular interest is paid to immigrants 'integration in the cultural environment of Latvia.

Conclusions. Positive changes in economic life, positive understanding in the mass media and study curricula are needed as they would promote formation of a positive understanding of the mobility and migration in multi-dimensional society nowadays.

Keywords: migration, mobility, understanding, multi-dimensional society
\end{abstract}

\section{INTRODUCTION}

Rapid inhabitant mobility and migration to European and other countries in the world as well as in the territory of Latvia goes on since Latvia has become the member of the European Union. There are several possible reasons for that: economic crisis in the country, low salaries in the social state sector, individual strivings and aspirations to achieve self-realization. Many children become parentless as parents go to different countries. A part of Latvia's inhabitants come back but a part of them continue to live abroad. This was the reason for choosing the topic to study.

Motives for work migration are: 1) hope to earn means of support for the family, flat renovation, education of children, purchase of property, vehicle, payment of loans; 2) wish to travel to other countries, study languages, obtain new experience; 3) social guaranties and normal life. A big part of them hope to fulfil these goals in a year, seldom in 2 or 3 years. On average many leavers have come back to their families after 2 years, a lot of them have started their own businesses. It is a reason why mobility and migration increases as a topical problem.

Understanding of Latvian studying youth about mobility and migration in a multidimensional society nowadays has been encouraged.

\section{THE AIM OF THE STUDY}

To investigate the circumstances why inhabitants of Latvia leave their country and what is the civic attitude of Latvian studying youth about mobility and migration in different society nowadays. 
Objectives: Investigate the current statistical information about mobility and migration from Latvia during the last years. Find out the students understanding of Latvian and European countries about mobility and migration from their countries.

\section{MATERIALS AND METHODS}

The term migration (Latin: migratio) is a movement from one place to another; people coming into the state or leaving it (external migration); movement into inside of the state (internal migration).

The term emigration (Latin: emigratio) means a voluntary movement of people (due to economical, political etc. circumstances) or forced movement of people to another country.

Immigration (Latin: immigrare) takes place when citizens arrive in another country for a temporary or constant stay.

It has been forecasted in Conrad Adenauer's fund materials that during the next 5-7 years those born in the 90's, when the birth rate was very low, will enter the labour market and Latvia will face a very serious lack of workforce. The highest reduction will be among the most capable inhabitants $-15 \%$ less than in 2005 . It is expected that by 2015 about 200,000 active people will gradually go to the countries of the EU due to economic, social and local market problems but in 2020 in Latvia there will be approximately 1.6 million people in the age group from 15 to 74 years (Indāns, 2006, 4-8).

Experience shows that after becoming the member of the EU in 2004 Latvia has not become a country of immigration because of its comparatively low social welfare as well as strict immigration policy.

According to the information from the Statistics Office Eurostat (SOE) the number of inhabitants in the EU in 2005 has increased by 2.3 million or $0.5 \%$, reaching 459.5 million, but the most rapid decrease of all the EU countries was in Latvia (Indāns, 2006, 8).

On the basis of population census of 2000 (Eurostat) 12.6 thousand people came to Latvia from 2000 to 2006, but 29.7 thousand long term immigrants left the country (Central Board of Statistics of Latvia Republic, 2007).

The number of foreigners in Latvia is reasonably low if we compare it with other European countries. The number of employed foreigners in Latvia in 2005 has increased by $54 \%$ in comparison with 2004 and making them into $1.56 \%$ of all the inhabitants of Latvia, but in the beginning of 2008 there were 46,353 foreigners (2\%) in Latvia (Indāns, 2006, 52).

The government of Latvia is interested in a flexible arrangement of the workforce from one sphere into another, thus not facilitating access of the third countries to the labour market in Latvia. There were about 12,000 vacancies in the labour market in Latvia in 2005, mainly in the state administration, health and social care, transport and communication spheres. The government of Latvia appeals to the employers to use the existing resources of workforce and it has not planned any activities to ease the access to the labour market for the third world countries' citizens in Latvia (Indāns, 2006, 4).

Many Latvian inhabitants support the state immigration policy. Statistic information shows that Latvia has the most negative attitude towards the immigration. $69.8 \%$ of Latvian inhabitants show a negative attitude against guest workers in Latvia - this was found out after the questionnaire made in December 2005 (Central Board Statistics). 17\% of inhabitants have a more positive attitude. $67 \%$ respondents consider that the government of Latvia should keep people from other countries away so they do not come to Latvia. Such a public opinion is connected with the consequences of the Soviet time migration policy, inner insecurity about one's own identity and fear from competition (SKDS, 2005, 36-37).

In the World Bank research Doing Business in 2006: Creating Jobs Latvia is in the 26th place in the category of starting new businesses (Doing Dusiness, 2006, 3, 92), but as regards inflexible legal work relations, Latvia is placed in the 103rd place among 155 countries of the world (Doing Business, 2006, 99). 
The workforce of Latvia now consists of the generation born in the 80-ties of the 20th century when the birth-rate in Latvia was at its maximum. Latvia will face a serious lack of workforce as soon as 200,000 people born in the 90's enter the job market, but 300,000 people will retire (Indāns, 2006, 8).

According to the information of the Economic Ministry of Latvia Republic, most part of workforce goes to Ireland, Great Britain and Germany. This number is about 5\% from the whole active workforce which is characteristic for all the new EU member countries (SKDS, 2005, 6).

Materials about migration by the Central Board of Statistics of Latvia Republic show that the long term migration tendency is going up in the year 2007: the number of immigrants increases and the amounts of emigration become stable. In Latvia at least about 3,200 people arrive a year $(2,760$ in the year 2006), but those leaving Latvia are 5,200 people (5,100 in year 2006) (Ušackis, 2007).

Prognosis of the reduction in the number of people in the year 2007 is 1,900 people due to emigration predominance over immigration (The number was 2,451 in the year 2006) (Ušackis, 2007).

The analysis of the domestic migration in Latvia shows that 55,089 people moved from one administrative territory to another in 2007. The clear tendency is to move to the capital Riga. 9,731 people moved to Riga in 2007 (Rumpīte, CSD, 2007).

Statistical data proves that the number of inhabitants in the first 9 months of 2007 has reduced by $0.38 \%$ due to internal migration in the state in general, but it has increased by 6,890 people nearly Riga (Rumpīte, CSD, 2007).

The lack of workforce offers in Latvia as a problem was recognized quite recently. Nobody paid attention to the possible social and economic consequences when 230,000 people or $10 \%$ of inhabitants left the country in the time period 1991-2004 (Darbaspēka Ģeogrāfiskā Mobilitāte, 2007, 37).

Problem range caused by migration intensified in 2005: 1) mobility (8,480) and migration $(8,470)$ are important questions in the whole EU as they have positive and negative socio-economical and demographic consequences; 2) it is important for every nation to preserve its cultural identity; 3) immigration control is significant in Latvia as well as particular interest is paid to immigrants integration in the culture environment of Latvia.

Sociological inquiry data in 2006 revealed that about $59.4 \%$ of Latvian inhabitants were positive to go away to other countries, $22 \%$ of respondents wanted to emigrate in the next two years. However, the common tendency to emigrate reduces (SKDS, 2005, 6).

People come to Latvia to make safe investments and to establish business there. There is highly qualified and rather cheep workforce in Latvia. People from the former Soviet Union arrive here as they get married there, their relatives and friends live there, there is no language barrier and Russian language can be used there.

The inquired inhabitants of Latvia more positively evaluate immigrants $(16 \%$ 43\%) from the Eastern countries. $41 \%$ do not accept guest workers from China, $32 \%$ - from Africa, $30 \%$ - from Vietnam, $28 \%$ mention other countries of Asia and Turkey (SKDS, 2005, 6, 45).

Different state institutions made the report in 2007 (Darbaspēka Ģeogrāfiskā mobilitāte) about actions how to succeed in returning the people from abroad back to Latvia. This report will be discussed in the Parliament of Latvia Republic in April 2008.

There were three groups of people involved in the formation of this report:

1. People who had worked abroad themselves or their relatives still working abroad;

2. Scientists and experts;

3. Business people of different branches, representatives of State and municipality 
institutions. The most important conclusion of the report - Social environment and the lack of guaranties prevent people from coming back to Latvia (DĢM, 2007).

There are mainly young people among migrants: about $33 \%-40 \%$ are up to 30 years old, $20 \%-25 \%$ are from $30-39$ years old (SKDS, 2005, 16).

Predominantly people with general or professional secondary education go away. The number of female with higher education prevails. The statement that the best and highly qualified workers leave is not true (Darbaspēka geogrāfiskā mobilitāte, 2007, 3).

There are 3 groups of migrants: 1) $10 \%$ think that they will come back to Latvia, they are interested in the events in Latvia, part of them have got the family in Latvia, part of them finance purchasing real estate property; 2) $10 \%$ do not want to come back because of various circumstances, they keep apart and try to obtain the citizenship of another country; 3) $80 \%$ hesitate but keep in contact with Latvia and help other people to go away from Latvia and to adjust in another country (DĢM, 2007; SKDS, 2005).

Motives for work migration are: 1) hope to earn means of support for family, flat renovation, education of children, purchase of property, vehicle, payment of loans; 2) wish to travel to other countries, study languages, obtain new experience; 3 ) social guaranties and normal life. A big part of them hope to fulfil these goals in a year, seldom in 2 or 3 years. On average many of them have come back to their families in 2 years, a lot of them have started their own business (DĢM, 2007, 4; SKDS, 2005, 7).

A part of people would be ready to return if: 1) the salary were the same or at least half so high as abroad; 2) state and employers supported families with children and felt respect against employees; 3 ) bureaucratic obstacles to establish one's own business were reduced; 4) people were mutually polite and smiling; 5) the church did not discriminate homosexuals and women - priests; 6) it was possible to get appropriate education for the market demands of the EU (DĢM, 2007, 4).

Demographic statistical data by the Central Board of Statistics about the number of inhabitants in 2000-2007 (see Table 1).

Table 1. Number of inhabitants until capacity to work, during capacity to work, above capacity to work in age groups and demographic load in Latvia in 2000-2007 (beginning) (Demogräfiskās statistikas galvenie rādītāji 2006. gadā, 2007, 3)

\begin{tabular}{|c|c|c|c|c|c|c|c|c|}
\hline \multirow[b]{2}{*}{ Year } & \multirow[b]{2}{*}{$\begin{array}{c}\text { Total } \\
\text { number of } \\
\text { inhabitants }\end{array}$} & \multicolumn{3}{|c|}{ Among them } & \multicolumn{3}{|c|}{ Proportion in $\%$ in total number } & \multirow[b]{2}{*}{$\begin{array}{c}\text { Demo- } \\
\text { graphic } \\
\text { load }\end{array}$} \\
\hline & & $\begin{array}{c}\text { Until } \\
\text { capacity } \\
\text { to work }\end{array}$ & $\begin{array}{c}\text { During } \\
\text { capacity } \\
\text { to work }\end{array}$ & $\begin{array}{c}\text { Above } \\
\text { capacity } \\
\text { to work }\end{array}$ & $\begin{array}{c}\text { Until } \\
\text { capacity } \\
\text { to work }\end{array}$ & $\begin{array}{l}\text { During } \\
\text { capacity } \\
\text { to work }\end{array}$ & $\begin{array}{c}\text { Above } \\
\text { capacity } \\
\text { to work }\end{array}$ & \\
\hline 2000 & $2,381,715$ & 428,082 & $1,402,249$ & 551,384 & 18.0 & 58.9 & 23.1 & 698.5 \\
\hline 2001 & $2,364,254$ & 409,760 & $1,424,985$ & 529,509 & 17.3 & 60.3 & 22.4 & 659.1 \\
\hline 2002 & $2,345,768$ & 390,478 & $1,425,116$ & 530,174 & 16.6 & 60.8 & 22.6 & 646.0 \\
\hline 2003 & $2,331,480$ & 372,641 & $1,454,536$ & 504,303 & 16.0 & 62.4 & 21.6 & 602.9 \\
\hline 2004 & $2,319,203$ & 356,505 & $1,457,858$ & 504,840 & 15.4 & 62.8 & 21.8 & 590.8 \\
\hline 2005 & $2,306,434$ & 341,415 & $1,473,805$ & 491,214 & 14.8 & 63.9 & 21.3 & 565.0 \\
\hline 2006 & $2,294,590$ & 328,547 & $1,477,108$ & 488,935 & 14.3 & 64.4 & 21.3 & 553.4 \\
\hline 2007 & $2,281,305$ & 318,463 & $1,489,839$ & 473,003 & 14.0 & 65.3 & 20.7 & 531.2 \\
\hline
\end{tabular}

To compare with 2006, the number of inhabitants in 2007 has reduced by 13,300 people. In accordance with the data of Citizenship and Migration Affairs Register the division among nationalities for 01.01.2008. is depicted in Table 2. 
Table 2. Structure of inhabitants of Latvia (Statistika par iedz̄̄votājiem, http://www.np.gov.lv/indexphp?lv=fakti_lv 16.04.2008.)

\begin{tabular}{|l|r|r|r|r|c|}
\hline \multicolumn{1}{|c|}{ Nationality } & \multicolumn{1}{c|}{ Citizens } & Non-citizens & $\begin{array}{c}\text { Foreigners } \\
\text { stateless people }\end{array}$ & \multicolumn{1}{c|}{ Totally } & \% \\
\hline Latvians & $1,342,215$ & 1,724 & 1,161 & $1,345,100$ & $59.1 \%$ \\
\hline Lithuanians & 18,385 & 10,245 & 2,150 & 30,780 & $1.4 \%$ \\
\hline Estonians & 1,496 & 573 & 435 & 2,504 & $0.1 \%$ \\
\hline Byelorussians & 31,196 & 50,008 & 2,595 & 83,799 & $3.7 \%$ \\
\hline Russians & 367,035 & 245,665 & 25,710 & 638,410 & $28.0 \%$ \\
\hline Ukrainians & 17,442 & 35,290 & 4,549 & 57,281 & $2.5 \%$ \\
\hline Polish & 40,635 & 12,693 & 793 & 54,121 & $2.3 \%$ \\
\hline Jews & 6,507 & 3,217 & 444 & 10,168 & $0.4 \%$ \\
\hline $\begin{array}{l}\text { Other } \\
\text { nationalities }\end{array}$ & 32,597 & 13,006 & 8,516, & 54,119 & $2.4 \%$ \\
\hline Totally & $\mathbf{1 , 8 5 7 , 5 0 8}$ & $\mathbf{3 7 2 , 4 2 1}$ & $\mathbf{4 6 , 3 5 3}$ & $\mathbf{2 , 2 7 6 , 2 8 2}$ & $\mathbf{1 0 0 . 0 \%}$ \\
\hline
\end{tabular}

\section{Empiric research}

433 respondents participated in the empiric investigation to find out the understanding of Latvian students against migration.

68 students from Riga, Cēsis, Tukums and Jēkabpils were interviewed. Two pedagogical Master students were interviewed, one had worked as a waitress in England for a year, the other had worked for some months; one bachelor programme student - returned from work in Ireland, one elder woman, working in the factory in England and one bachelor programme student who studied in the United States for a year.

\section{RESULTS}

The question about the reasons of migration and the attitude against oneself: one respondent told that she wanted to go because she had debts and she wanted to start something new. Living conditions were good, the workplace was prepared. The attitude was good, she had worked in a cafe, washed dishes, prepared salads, earned good money. Feels uncomfortable in Latvia.

The second respondent ( 3 months in Great Britain): 40 years old, divorced. Essential to study the language and to earn money. There were already 7 people from her parish, two children in Latvia. It was possible to buy Latvian things in Latvian shop. It was difficult emotionally, she could not go to her daughter's final school leaving ceremony, but she had earned enough money to pay for her both daughters studies. Contacted home by telephone. That had been the time for self-communication. Culture environment was good as she had interested about everything internet, magazines, and newspapers both in Latvian and in English. Latvians are the nation who stick together, celebrate events together. Attitude had been very positive everywhere - smiling and polite people in the hospital and in service sphere. That is missing in Latvia. It is not well that some migrants live the double life - one family in Latvia, one - abroad. After obtaining Master's Degree will return to England as there are social guaranties, arranged state system and financial security.

$3^{\text {rd }}$ respondent ( 23 years): went away together with her husband, worked as a waitress. Earned money, the attitude was good but she missed Latvia as the life in Ireland had been solitary and monotonous. She got pregnant and they both went back to Latvia as she had got much to do in Latvia. She does not want her place to be taken by guest workers.

$4^{\text {th }}$ respondent: $3^{\text {rd }}$ year in England. Was forced to leave Latvia as could not find job in her pre-pension age. Difficult at the beginning, the environment unknown and unprepared. 
Worked in the hotel service, now work in some factory. Intelligent, is interested in art, culture, reads a lot, travels. Especially praises social guaranties and possibilities to go to Latvia several times a year. Is not going to return as there are no social guaranties and the state does not care about the people.

The 5th respondent had studied in the college in the USA and had come back as she could not accept students' negative attitude against studies. She considers that studies in Latvia are on a good level. She wants to work in the primary school and to pursue her competence to primary school pupils.

There are many migrant interviews on the internet about life and work possibilities in Ireland. For example, one driver works in Ireland for five years already. The reason for leaving Latvia - needed money to rebuild the house. He did not have work here. The friend invited to Ireland. Before that he got the driver's licence in all categories and studied some English in the courses. In Ireland he studied language in the evenings, during the daytime worked in the green house where salad was grown, at weekends worked in the vegetable warehouse. Found the job on the lorry.

The living conditions are good, four Latvians live in the same house, forty minutes by tram to get the centre of Dublin, by bike - 10 minutes.

Salary in Ireland is from 9 to 14 EUR per hour. Employees are well cared about. Trade unions are strong that is why the social guaranties are so good.

The Ministry of Integration wants foreigners to join the society as it is important for people to work legally and to pay taxes.

There are many Latvians, Lithuanians, Byelorussians, Polish, so it is possible to communicate in Russian.

Latvian women often get married to Pakistani and Indians or Afro-Americans. There are many Muslim people but they do not integrate in the society.

Work five days a week. At weekends the payment is double. Do not sit at the TV in the evenings. Join the social life. Dance in the folk dance group 'Jampadracis'. A concert for Latvians in England. In 2008 will take part in the Latvian Song and Dance festival in Latvia. In Ireland there is Latvian newspaper Sveiks. There is church service for three years in Dublin, in the rented German church building.

Men are quite passive. Some of them do not go anywhere, cannot dance or sing. Some have bought or have built their house (Lipsnis, 2008, 8-9).

Enterprising people seek for works and find them. It means that people are mobile. It is difficult for people in pre-pension age to find a job as there is big competition.

Young people want to compete in the work market in Europe so they study languages, communicate without problems, decide, are opened to new impressions, and are determined and mobile. The way of thinking in Latvia has changed and it continues to change. Time ago the wish for the nation was to keep together now prosperous life is more essential than the idea. Our philosopher Rubenis said that self destruction of the nation would take place if the nation does not feel respect against its land or forgets its language (Rubenis, 1994, 16).

Migration has influenced the whole Latvia. The family does not fulfil its duties in children's upbringing. The role of school has changed. Observations in Jurmala State Gymnasium and in the state in general show that about $10 \%$ parents of children work away from Latvia. The children have guardians. Their material needs are satisfied but they are not brought up. School prepares their life skills. The goal of school is to bring up a person for work and education market.

Latvian students' understanding about migration and mobility was found out with the help of mediatisation method. In accordance with investigation specific 359 Latvian students of 20 groups from Alūksne, Cēsis, Daugavpils, Jēkabpils, Kuldīga, Bauska, Ventspils and Rīga were interviewed. There were 38 questions in the questionnaire. 
In questions 1-9 students' understanding and interest about migration (q-s 2\&3) was found out, knowledge about statistics (q-s 4\&5), attitude against migration to Latvia (q-n 7), from Latvia (q-n 8), attitude against the inner migration.

$79 \%$ respondents tell they know the meaning of terms migration and mobility; $15 \%$ respondents do not know the meanings; $1 \%$ respondents are not interested in the terms, but 5\% respondents give different answers. In Latvia: partly, guess, about, do not know mobility, and have never thought about it.

\section{Picture 1. Concepts of migration and mobility}

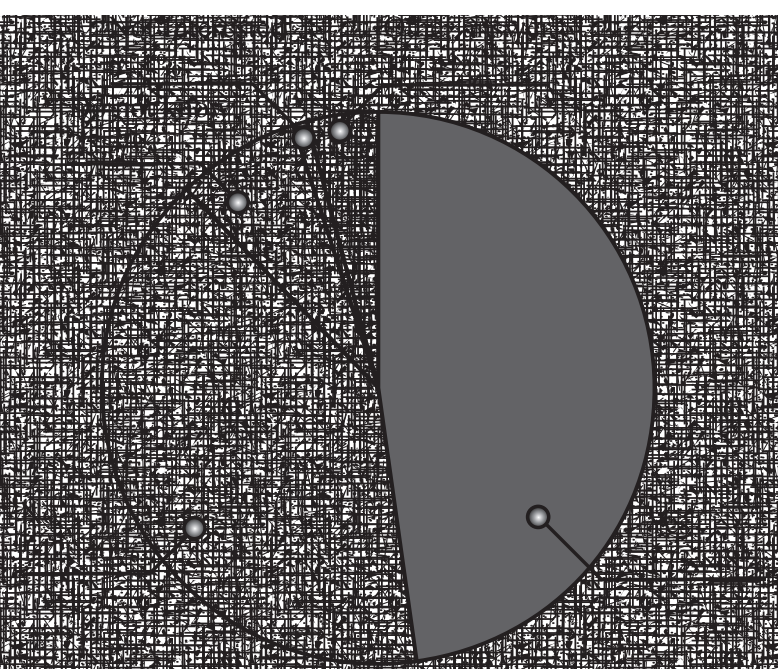

Evaluating the questions about migration we can make decisions that this questionnaire had made students of Latvia think about migration from the country. It is negative as the youth is needed in our own country.

Question 7 - attitude against migration to the country.

Picture 2. Understanding about mobility and migration to the country

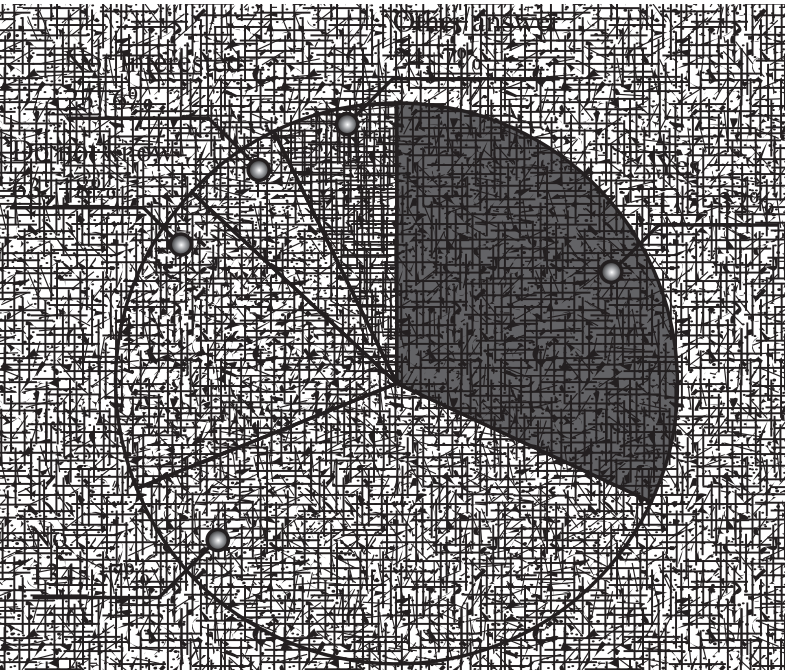


Students of Latvia: $37 \%$ - against migration to their country; $32 \%$ - to migration to their country; $18 \%$ - do not know; $6 \%$ - are not interested in the question; $7 \%$ - have a different answer, for example, no objection or neutral; cheaper workforce coming to the country - it is good; both - positive and negative attitude.

Students' international travel experience was looked upon (q-n 10): 228 had travelled abroad, gained positive experience, and enjoyed that. 274 respondents answer (q-n 12) - would go away for some months to half a year; 135 - could live, 142 - could not live outside Latvia during 1-3 year period (q-n 11).

303 respondents care about their cultural identity (q-n 30), 233 respondents think that cultural identity of other people is important for them, 48 - not important (q-n 31); 290 respondents - human's identity is not significant (q-n 32), 300 - it is significant, 10 - not, 24 - do not know, 4 - not interested if they are sensitive against others in communication ( q-n 33), 21 have other answer - it does not matter nowadays if the others are sensitive.

Question 35 about the influence of migration on cultural identity the students of Latvia that migration has both - positive (34\%) and negative (24\%) effect on migrants themselves, on their relatives as well as on the society in common, $26 \%$ answer that they do not know, $8 \%$ have other answer: in the time of globalisation patriotism vanishes, national identity becomes less important, assimilation of culture takes place, there is no stability, the world gets divided. Migration is a natural process until the equal economical welfare is being achieved.

\section{Picture 3. Migration effect on cultural identity}

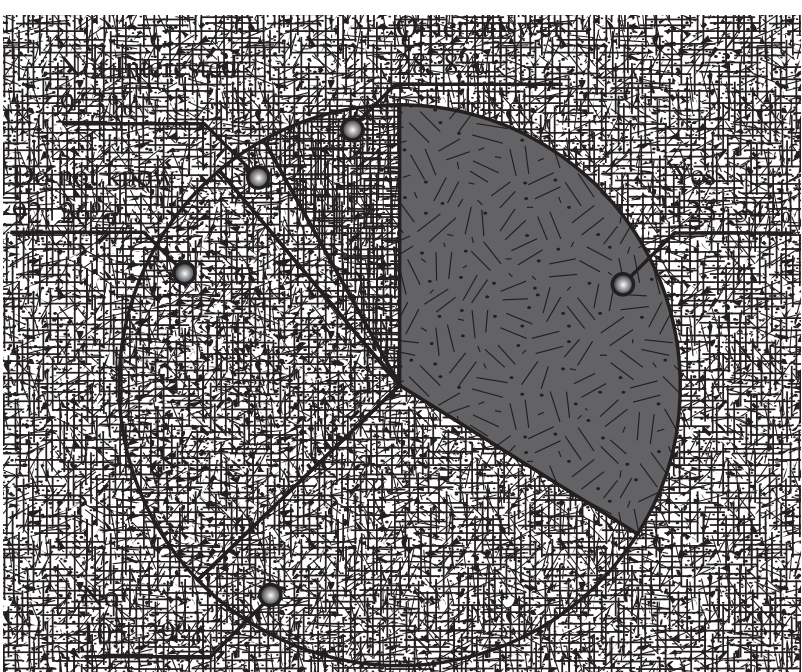

Positive migration is new experience and emotions, language acquisition in practice, learning world's cultures and traditions, possibility to earn money and help the family. Materially and mentally rich person can enrich his country. It is important for a person to be aware of one's membership to the country Latvia. In essence a person is a seeker, he wants a better life. For every person it is individually, both positive as well as negative.

Negative aspects are observed in the inner and outer migration: families break apart, races get mixed, cultural identity of the nation is damped down, and children are left with relatives, friends, tutors, acquaintances. Migrant children emotionally get alienated from parents, family traditions are not inherited. The worst thing is that people do not return to their country. 
Culture identity is important for our nation to survive. Economical problems have to be solved as satisfied basic needs will motivate people to attest themselves in the sphere of culture. But we have to admit that we give away our educated young people.

In pyramid of needs by Maslow we see how important it is to satisfy physiological needs as they are followed by safety. A person wants to feel safe and protected. Particularly the growing child needs to be supported, and this support he can mainly get in school.

Mobility for students is the movement from one side. Mobility is the skill to organise one's life as he wants. The opinion exists that mobility is the skill to adjust, move, it is flexibility, operativeness, quick reaction in unknown conditions. A mobile person is active, possible to adjust to new, is free, flexible, perceives new cultures. Real life promotes different way of thinking: feeling of distance changes - one can go by car for $250 \mathrm{~km}$ in about 4 hours, but by plane to go even bigger distances in 2 hours.

\section{CONCLUSIONS}

Research of theoretical sources shows that in Latvia both internal and external migrations take place. The number of inhabitants in Latvia is gradually decreasing every year. The main reason for the mobility and migration is the low salary. Latvian students proved that Latvians are better disposed to their country and its cultural identity. The positive factor is that the students become aware of the migration processes and become more mobile. The state has to change its understanding of the inhabitants'wishes and satisfy the economic and social demands. Education must be provided in accordance with the regulations of the EU labour market.

Positive changes in the economic life as well as a positive understanding in the mass media and study curricula is needed as they promote the formation of positive understanding of mobility and migration in the contemporary multi-dimensional society.

\section{REFERENCES}

1. Darbaspēka geogrāfiskā mobilitāte [Geographical Mobility of Workforce. Group Leader of the Research Work]. (2007) LR LM Pētījuma darba grupas vadītāja Zaiga Krišjāne. Rīga: LU, 240 lpp. http://sf.lm.gov.lv/esf/print.php?doc_id=39 (04.07.2008.) (in Latvian)

2. Demogrāfiskās statistikas galvenie rādītāji 2006. gadā: Īss informatîvs apskats [Main Rates of Demographical Statistics of 2006. Short Informative Survey]. (2007) Rīga: LR CSP, 6 lpp. (http:// www.csb.gov.lv/) (07.07.2007.) (in Latvian)

3. Doing Business in 2006: Creating Jobs. The World Bank Research. (2006) 192 p.http://www. worldbank. org (07.07.2008.)

4. Latvijas imigrācijas politika: problēmas un perspektīvas [Imigration Policy of Latvia: Problems and Perspective]. (2006) Rīga, 563 lpp. http://www.lddk.lv/file.php?id=32 (13.04.2008.) (in Latvian)

5. Lipsnis, J. (29. marts, 2008) Šopavasar bija paredzēts atgriezties [It was Supposed to Come Back this Spring]. Kurzemnieks, Sestdiena. Nr. 37 (9786), 8.-9. lpp. (in Latvian)

6. Par 2007. gada demogrāfiskās situācijas provizoriskajiem rezultātiem [About Average Results of Demographical Situation in 12.12.2007.]. (12.12.2007) http://www.csb.lv/csp/events/csp/ events $/$ mode $=$ arh\&period $=12.2007 \& c c \_c a t=471 \& i d=2983(03.01 .2008$. $)$ (in Latvian)

7. Ilustrētā svešvārdu vārdnīca [Illustrated Dictionary of Foreign Words]. (2005) sast. Andersone, I., Čerņevska, I., Kalniņa, I., Nātiņa, D., Puriņa, R., Vjatere, L. Rīga: Avots, 891 lpp. (in Latvian)

8. Par iedzīvotāju ilgterminga migrāciju Latvijā 2007. gadā [About Long Term Migration of Inhabitants in Latvia in 2007]. (2007) CSP dati. http://www.csb.lv/csp/events/csp/events/?mode= arh\&period $=04.2008 \& c c \_c a t=471 \& i d=5636$ (25.04.2008.) (in Latvian)

9. Rubenis, A. (1994) Cilvēks mītiskajā pasaules ainā [A Human in the Scenery of Mystical World]. Rịga: Zvaigzne, 140 lpp. (in Latvian) 
10. Sabiedrības attieksme pret darbaspēka migrāciju: Latvijas iedzīvotāju aptauja 2005. gada decembris [Attitude of Society Against Workforce Migration. Questionnaire of inhabitants in Latvia in December 2005]. (2005) SKDS pētījums. Rīga, 58 lpp. (www.skds.lv) (01.02.2007.) (in Latvian)

11. Statistika par iedzīvotājiem: Latvijas iedzīvotāji sadalījumā pēc tautībām [Statistics about Inhabitants: Division of Inhabitants according to Nationalities]. Pēc Pilsonības un migrācijas lietu pārvaldes Iedzīvotāju reǵistra datiem 01.01.2008.http://www.np.gov.lv/index.php?lv=fakti_lv (16.04.2008.)

Assistant professor Dr. paed. Sandra Rone

Riga Teacher Training and Educational Management Academy

Address: Atpūtas iela 8, Piṇki, Babītes pag., Rīgas raj., LV-2107

Mob. phone: +37129299831

Fax: +37167735842

E-mail:sandrarone@yahoo.com

Asoc. prof. Dr. paed. Anna Lìduma

Riga Teacher Training and Educational Management Academy

Address: Grobiņas iela 3 dz. 12, Riga, LV-1004

Mob. phone: +37129807233

E-mail: anna.liduma@rpiva.lv 